\title{
SOCIAL CONSEQUENCES OF TAXREFORMS
}

DOI: $\underline{10.15826 / \text { jtr.2015.1.1.008 }}$

УДК 336.02

\author{
V. P. Vishnevsky, Doctor of Economics, Professor, \\ Institute of the Economy of Industry of the NAS of Ukraine, \\ Kiev, Ukraine \\ Gurnak A.V., Candidate of Economic Sciences, Associate Professor \\ Moscow, Russia
}

\section{TAXATION, EVOLUTIONARY ECONOMICS AND TAX POPULATIONS}

\begin{abstract}
The article applies an evolutionary approach to the study of taxation which, in contrast to neoclassical economics and institutionalism, is focused on the long-term perspective and population determinants of the tax system development. This approach is an element of a new - evolutionary - tax paradigm. The pivotal idea of this paradigm is the idea of tax populations, whose habitats may fall beyond the state borders, as the latter are historically contingent and often unite people who belong to different genetic and socio-cultural communities.

The article presents an empirical and logical investigation of the main tax population. Empirical results are based on the use of the clustering method for the sample including 117 countries. As shown by the undertaken analysis, there are, indeed, groups of countries in the world relatively homogeneous in selected indicators that can be interpreted as some supranational model of tax systems. The clusters obtained, along with a logical analysis of the social and economic development of different countries of the world, allowed us to identify and describe the core features of the main tax populations which are the European, the Chinese-East Asian, The Maghrebi-Middle Eastern, and the Indian-South Asian tax populations.

The concept of main tax populations proposes a new methodological base for tax policy and tax reform activity. This does not mean that the neoclassical recommendations on tax policy and reforms are unimportant in principle, but they must be used primarily as a means of streamlining the tax system within the tax population with regard to its specific context, subject to evolutionary problems of population growth, not as universal recipes for all occasions.
\end{abstract}

Keywords. Taxation; methodology; evolutionary economics; institution; tax population; tax system; tax policy; tax reform.

\section{Introduction}

The tax systems of the world are very diverse. Among them there are those that perform the functions entrusted to them well, and yet there are clear underdogs. For example, those tax systems that are now in the former Soviet Union states (Russia, Ukraine, Belarus) and summarize the twenty five-year natural experiment (1991-2015) in the market transformation of a planned economy — are not the best sample. At least, the reports "Paying Taxes", periodically published by PricewaterhouseCoopers and the World Bank Group, classify the tax systems in these countries as the least favourable to business development. It turned out that following the neoclassical prescriptions of reforming and copying foreign tax experience (in this case, European) had not led to the desired results; rather, it may be well summarized by the former Prime Minister of Russia Viktor Chernomyrdin' famous formula: "We tried our best - you know the rest". Thus, similar tax norms (VAT, personal income tax, corporate income tax, etc.) work differently in different settings.

1 Vishnevsky Valentine - Doctor of Economics, Professor, Academician of NAS of Ukraine, Deputy Director of the Institute of Industrial Economics of National Academy of Sciences of Ukraine, Kyiv, Ukraine (01011, Kyiv, str. P. Mirnogo, 26); e-mail: vvishn@mail.ru.

Gurnak Aleksandr - Candidate of Economic Sciences, Associate Professor of Taxes and Taxation Department, Finance University under the Government of the Russian Federation, Moscow, Russia Federation, (125993, Leningradsky Prospekt, 49), e-mail: gurnak@rambler.ru. 
In order to identify the causes of this situation and explain how it could happen, it is necessary to expand the traditional horizon of tax research and to analyse not only the current tax issues and the routines already established (what can be called an analysis "within the rules"), but also the issues of long-term strategy development, of scientific vision of the tax system's future, and regularities in the change of economic entities' behaviour in space and time, that is, their evolution.

This paper is organized as follows. In the first section we briefly review the existing economic paradigms and their effects on taxation research. In Section II, we explore the scope of conditions for using an evolutionary approach in the study of taxation and define the notion of tax population. It is argued that this approach promotes our understanding of such complex socio-economic process as taxation, and builds a new methodological base for tax policy and tax reform activity. Section III presents an empirical and logical investigation of the main tax population. Empirical results are based on the use of the clustering method for the sample including 117 countries. The clusters obtained, and a logical analysis of social and economic development of different countries of the world allowed us to identify and describe the main features of the main tax populations which are the European tax population, the Chinese-East Asian tax population, The Maghrebi-Middle Eastern tax population, and the Indian-South Asian tax population. Conclusions are drawn in Section IV.

\section{Main Economic Paradigms and Taxation}

Traditional methodology of scientific research in the field of taxation is the neoclassical theory of welfare economics, coming from the postulates of methodological individualism and rational behaviour of economic agents, taxation of whom leads to changes (growth or loss) in social welfare $[1 ; 2 ; 3]$. Transaction costs in the neoclassical world are either absent altogether, or present as minor "obstacles", or "noise". A starting point of the theory is the utility-maximizing abstract egoist who acts rationally under conditions of his full awareness. Therefore, popular textbooks on public finance, for example, Musgrave and Musgrave (1973) [4], Atkinson and Stiglitz (1980) [5], Rosen and Gayer (2008) [6], usually do not analyse the historical features of the tax cultures and traditions of different countries and civilizations, which, in real life, significantly affect the choice of targets and methods of the tax policy implementation.

Tax institutionalism introduces specific historical aspects of economic relations into the economic theory through the adoption of the postulates about the bounded rationality and information awareness of the economic agents, their opportunistic behaviour [7]. The relationship among the subjects is structured by the rules (restrictions) those deliberately created by people and/or spontaneous ones. The institutional world, in contrast to neoclassical, is a universe in which the transaction costs are not just some "noise", but one of the main factors that determine the development of the economy. So, for example, the differences in the national economies' performance and the tax systems of the border states (South and North Korea, the former West and East Germany, etc.), incomprehensible from the standpoint of neo-classics, can be explained by differences in the institutions' efficiency [8].

The very question about national economies and the types of tax systems implicitly points to the importance of geographical, genetic, cultural and historical aspects of the economic problems that lie outside the institutional paradigm, and reveals the framework of its use. As noted by Diamond (1994): “... there is increasing recognition that this good-institutions view is incomplete - not wrong, just incomplete and that other important factors need addressing if poor countries are to become 
rich. This recognition has its own policy implications. One cannot just introduce good institutions to poor countries like Paraguay and Mali and expect those countries to adopt the institutions and achieve the per-capita GNPs of the United States and Switzerland ... Good institutions are not a random variable that could have popped up anywhere around the globe, in Denmark or in Somalia, with equal probability. Instead, it seems to me that, in the past, good institutions always arose because of a long chain of historical connections from ultimate causes rooted in geography to the proximate dependent variables of the institutions" [8, p. 439].

Evolutionary theory is critical especially in relation to the static analysis of the economy. The evolutionary approach recognizes the permanent character of changes as the main characteristic of the economic reality. They are thought to emerge not as a short-term phenomenon designed to restore the equilibrium impaired under the influence of exogenous factors, but as a regular feature of economic systems.

Although the presence of permanent changes is recognized by all economistsevolutionists, yet there are some disagreements on the scientific explanation of the nature of these changes [9, pp. 550$551 ; 10$, p. 343]. The representatives of one scientific approach prove that the biological theory of evolution is the bearer of the general ontological logic that can be applied to all kinds of evolutionary processes, including social [11]. The representatives of the second approach, on the contrary, argue that generalized Darwinism is not able to cover the important features of cultural development and, therefore, is no more than an analogy which can be misleading [12].

In any case, the evolutionary theory extends the scope of its application in economics [9, pp. 547-548]. The specific feature of this theory lies in the fact that it introduces the principles of geographism, biologism, and historicism in the scientific analysis. From its standpoint, a man with congenital and/or acquired inclination towards selfish or altruistic behaviour is part of a geographically separate and self-reproducing population of organisms, the development of which is determined by the laws of genetic and cultural co-evolution [13]. The rules of interaction among people and the organizations created by them are not set once and for all, but are changed, inherited and selected.

Despite the fact that the evolutionary economy offers great opportunities to explain long-term economic development, research of the tax systems' development based on an evolutionary approach has still been rare, while the results received are fragmentary $[14 ; 15 ; 16 ; 17 ; 18]$. The reason for such state of affairs is seen in "obsession" with the current tasks of the fiscal policy and the lack of clear strategic vision of the problems, underpinned by an understanding that a single Western-style liberal world, as well as a unified neoclassical theory, has failed. The reality, as always, turns out to be more complicated. The world's new economic order is not a globalist unity, but a multipolar world of competing civilizations and world's regions that continue to unite around the "core countries". Economic theory is not the neoclassical unity (neoclassical synthesis) either, but the complexes of interrelated concepts, which are competing for the best explanation of the same sphere of economic phenomena (or intersecting spheres of phenomena) and for the forecast of the future development.

\section{Formation of the 'Hard Core' of the Evolutionary Taxation Paradigm}

The search by the former socialist and newly developing countries of their place in this new multi-polar world, which provides, inter alia, the formation of national tax systems, requires intensification of studies that proceed from the new view of the tax issues, and building consensus concerning the "hard core" of an evolutionary approach to studying the patterns of tax systems development.

This core can include the following basic assumptions. 
1. The subjects of tax relations (taxpayers and tax authorities) are heterogeneous, prone to altruistic type of behaviour (cooperation with public authorities, tax compliance and rejection of corruption) or to the selfish type of behaviour (defection of public authorities, tax evasion and involvement in corrupt transactions). Explanation of feasibility of economic entities' cooperation, which goes beyond the neoclassical analysis, can be found in the ideas of evolutionary selection and fitness [19], particularly in the sociobiological theory of multilevel (individual and group) selection, according to which group selection is favourable for cooperative subpopulations of subjects [13]. Moreover, co-operators can form clusters that increase the likelihood of cooperation with other co-operators to invade the space of egoists (defectors) and expand its presence in it [20]. They form tax populations united by a common territory and dominant institutions - spontaneous and formal rules with enforcement mechanisms for their implementation, which result from years of interactions among these agents in a specific geographic, biological and sociocultural environment. Depending on the history of its formation in that environment (the concept of "path dependence"), tax populations differ from one another so that the same causes have different consequences in different populations.

\footnotetext{
2 Meme is a "unit of cultural information acquired through the imitation of others" [21, p. 379]. Memes in taxation are exemplified by the ways of tax evasion, originally found by specialists of one or more enterprises, and then quickly spread through simulation around the entire tax population. This phenomenon is important for the reason that tax legislation, in principle, cannot give answers to your questions in the economy, especially in relation to such complex entities as income and value added. So, in practice, there is always a need for informal interpretation of formal tax rules. And if such a treatment has been successful, it eventually becomes part of the fiscal institutions specific to this population.

${ }^{3}$ Habit is an "individual dispositions to engage in previously adopted or acquired behaviour, triggered by specific stimuli" [21, p. 379]. The same ways of tax evasion applied repetitively, become a habit in taxation,
}

2. Tax institutions evolve over time: they are changed (as a result of genetically and culturally conditioned taxpayers' responses to environmental changes), selected and inherited. This occurs through the social processes of tax memes ${ }^{2}$ and habits ${ }^{3}$ transfer - on the individual level, and tax routine $^{4}$ - on the level of organizations and society, which can be regarded as social replicators (units of heredity) [21].

This process is cumulative and irreversible and results in growing complexity of tax institutions. The long history of taxation - from archaic natural duties to modern taxes, which are levied in a non-cash form and require sophisticated accounting, public reporting, complex institutions of their verification and validation - is a strong argument in favour of the fact that tax systems, indeed, possess those qualities.

3. Evolution of tax institutions leads to a change in the relative competitive positions of certain tax populations, so that some populations are growing, thus expanding the sphere of influence of their dominant fiscal institutions, while others are reduced (degrade). Thus, evolutionary selection is multi-level (the concept of "multiple levels

that is, a propensity "... to repeat the same act in similar material conditions" [22, p. 16]. Another example of tax habit is a widespread accounting principle of prudence, when financial professionals in a situation of uncertainty prefer to estimate assets on a low value, and obligations (including taxes) — on a high value.

${ }^{4}$ Organizational routine is «organizational dispositions to energize conditional patterns of behaviour within an organized group of individuals, involving sequential responses to cues» [21, p. 379]. An example of an organizational tax routine is a set of agreed actions of company specialists working with tax authorities that are usually performed by them in the event of a tax audit. In a broader sense, organizational routines are the order (religious, civic, economic), based on the requirements, including mandatory (normative), on how to act in a given situation [23, p. 6]. For example, tax legislation is prescriptions of how a business has to treat certain business transactions for tax purposes, what to do in the internal revenue service if the taxpayer fails to pay taxes in full and on time, etc. For more information about organizational routines, see Becker (2004) [24], Becker (2008) [23]. 
of selection" [13]) and occurs not only on the level of economic subjects, but also on the level of tax populations.

The proposed conceptualization of tax systems research based on an evolutionary approach which, in contrast to neoclassical economics and institutionalism, is focused on the long-term perspective and population determinants of the tax system development, is one of the elements of the new evolutionary - tax paradigm.

The pivotal idea of this paradigm is the idea of tax populations, whose habitats may fall beyond the state borders, as the latter are historically contingent and often unite people who belong to different genetic and socio-cultural communities. The priority for further research is to identify correctly such tax populations and to define the limits of their habitats. For this, one should take into account at least three groups of geographically overlapping factors: evolutionary-biological, civilizationalcultural, and socio-economic (Fig. 1).

The importance of considering the evolutionary and biological factors is determined by their influence on the characteristics of human behaviour, including their preferences and the type of rationality [25], which are of fundamental importance in the economic theory. Modern evolutionary psychology comes from the fact that " ... each level of cognitive and behavioural complexity is acquired slowly, gradually, through generation upon generation, over eons of time" [26, p. xiii], and that “... complex mental functions including higher order consciousness exist for the same reason that complex morphological and physiological characteristics exist" [26, p. 11]. Herewith, historically established ethnic groups (races) are characterized by their specific features of action, depending on intelligence (specific reasoning, approaches to problem solving, memorizing, etc.). It should be specially emphasized that, in this case, we are not speaking about value judgments in terms of "better - worse," especially from the standpoint of the hypothetical superiority of the Western world, but only about the existing

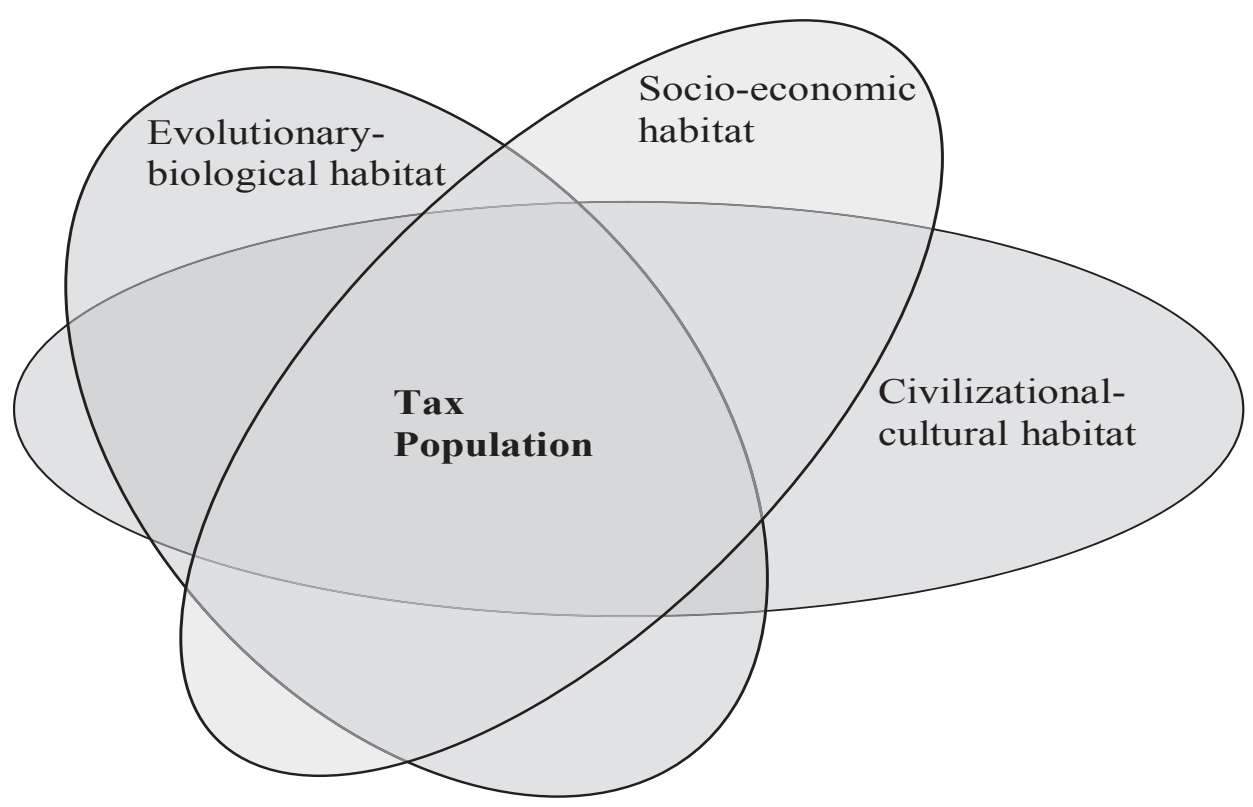

Figure 1. Graphical interpretation of tax population habitats 
stat of evolutionary diversity of behavioural patterns that characterize specific holistic lifestyles of races and ethnic groups, which are reflected, among otrher things, in their IQ which, in turn, is only one (and quite imperfect) of the approaches to assessing the multifaceted capabilities of people. According to the observations by J. Diamond, the inhabitants of New Guinea on average are more intelligent, more alert, better able to express their ideas and active interest in the world around them than the average Europeans or Americans, so that "[a]t some tasks that one might reasonably suppose to reflect aspects of brain function, such as the ability to form a mental map of unfamiliar surroundings, they appear considerably more adept than Westerners" [8, p. 20].

So, on the one hand, there are compelling arguments in favour of the social conditioning of the intellect, that the growing child is developing under the influence of training he receives, of the intelligence valued in the family environment, of the available training materials and hundreds of other social factors [27]. But, on the other hand, biological aspects also play an important role. As Lynn emphasises, "[t]he position of environmentalists that over the course of some 100,000 years peoples separated by geographical barriers in different parts of the world evolved into ten different races with pronounced genetic differences in morphology, blood groups, and the incidence of genetic diseases, and yet have identical genotypes for intelligence, is so improbable that those who advance it must either be totally ignorant of the basic principles of evolutionary biology or else have a political agenda to deny the importance of race. Or both" [28, pp. 159-160]. A long-time scientific debate about what has a greater effect on intelligence - nature or nurture - still remains a subject of controversy among modern environmentalists and geneticists, and so far the chances of the parties have been about 50 to 50 (Tayyari 2004 [29]; see also Richerson and Boyd 2005 [30], Richerson, Boyd and Henrich 2010 [31]).
Fiscal institutions of this population depend on historically established civilizational and cultural forms of organizing human life and activity, their shared cultural values, especially religious, which are inherent in all peoples. Civilization, by Huntington (1996) "... is thus the highest cultural grouping of people and the broadest level of cultural identity people have short of that which distinguishes humans from other species. It is defined both by common objective elements, such as language, history, religion, customs, institutions, and by the subjective self-identification of people" [32, p. 24]. Together, they determine the institutions, dominant in a given society, that guide human behaviour, including the one related to the state and taxes. As noted by M. Weber, "[n]o economic ethic has ever been determined solely by religion. In the face of man's attitudes towards the world - as determined by religious or other (in our sense) 'inner' factors - an economic ethic has, of course, a high measure of autonomy in the highest degree. The religious determination of life-conduct, however, is also one - note this - only one, of the determinants of the economic ethic" [33, p. 268].

Islam is a typical example, as it is considered one of the strongest and most viable religions today, and contains a special complex of economic and ethical standards, such as help to the poor, the denial of usury, etc. But at the same time, for the purposes of this study, it is important to take into account that Islam binds nations very different in all senses, such as the Indonesians, Kurds, Moroccans, etc. Therefore, as Huntington says, “... civilization and race are not identical. People of the same race can be deeply divided by civilization; people of different races may be united by civilization. In particular, the great missionary religions, Christianity and Islam, encompass societies from a variety of races. The crucial distinctions among human groups concern their values, beliefs, institutions, and social structures, not their physical size, head shapes, and skin colours" [32, p. 42]. 
Finally, the socio-economic factors are also important in identifying tax populations, since they determine the economic potential and specific features of the economic order created by people that has its own value — in addition to the factors of biology and culture. The level of economic development and its ability to generate value, and, even to a greater extent, the tax ratio characterizing the level of cooperation among people to create public goods, their relationship to the state and the institute of power as such - these are fundamentally important features of tax populations that determine the opportunities for their sustainable development. It is important to note here that historically established differences in distributing the economic potential among different peoples can be explained by those factors that J. Diamond figuratively called "guns, germs, and steel". But the roots of these differences should be searched in the physical and biological geography (taking into account the achievements of modern genetics, molecular biology, biogeography, behavioural ecology, molecular biology, epidemiology, etc.) [8, p. 25]. In this connection, it is easy to notice that the level of taxation (tax ratio) in a country is determined not only by the features of the dominant behavioural traits and cultural values, but also by the objective (depending on geographic factors) needs for funding public goods, necessary for the survival and success of society in conditions of the local area. This is evidenced, for example, by the fact that the Nordic countries with lower average annual temperature usually levy greater taxes per capita than the countries of Southern Europe.

Language is also a fundamental civilizational and cultural factor. Yet, as far as tax populations are concerned, the subjects of tax relations have their universal means of communication accounting, based on the

\footnotetext{
5 This fact makes possible inter-state comparison of taxes, such as, for example, annual "Paying Taxes" from PricewaterhouseCoopers and the World Bank Group
}

rule of double-entry. Modern taxes are primarily liabilities of corporations, based on the principle of limited liability and legally obliged to keep records and prepare financial statements. Therefore, the main objects of taxation - documented income and value added of corporations and their assets, income of those engaged in business, which is part of the economic costs - are everywhere the same (if you ignore the details) 5 . It is important to emphasize that, in our understanding, tax populations do not cover the whole economic space of the world, but only that part of it where there operate institutions and organizations providing documentary accounting of transactions and the regular calculation and payment of taxes based on it.

Thus, to identify tax populations' areas, a working hypothesis proposes a methodological approach based on a combination of races (ethnic groups), religion (worldviews) and taxes (per capita considering transaction costs) cartographies.

\section{Tax Populations: Identification and Analysis}

\section{Empirical analysis (clustering} countries). In the static aspect, a tax population can be represented as a group of countries in which tax systems operate in a similar manner, are equally responsive to changes in the same evolutionary-biological, civilization and cultural and socio-economic factors, and have a relatively similar level of the relevant parameters. Cluster analysis allows us to identify relatively homogeneous groups of countries, which can be interpreted as tax populations.

To perform this analysis, we used 19 different indicators that characterize the effect of various factors on the formation and development of tax populations, for a sample covering 117 countries. All these countries are different in terms of economic development, and are located in different geographical regions. The indicators reflect either their state in 2011, or the averages over a number of years. 
The group of indicators that reflect the influence of evolutionary-biological factors, include population figures (data source: Index of Economic Freedom from The Heritage Foundation), and the climate: the average temperature of the cold months (January or July) and the average temperature of the hot month (January or July) (Climate Change Knowledge Portal from The World Bank Group).

Estimation of the influence of institutional and cultural factors was based on the indicators of the dominant religion (The World Factbook from Central Intelligence Agency, USA), the size of the shadow economy [34], corruption perception (Corruption Perception Index from Transparency International), and a number of indicators that characterize the state of a country's institutions and are used in the calculation of The Global Competitiveness Index from the World Economic Forum, namely: property rights, public trust of politicians, irregular payments and bribes, wastefulness of government spending, and ethical behaviour of firms. The values of the last five indicators are measured on a scale from 1 to 7 , hence, a greater value of the index indicates a more effective functioning of the relevant institution, and a higher number implies a better state of the world. The predominant religion is coded as 1 for Christianity, 2 - Islam, 3 - Buddhism and 4 for other religions.

The socio-economic factor in the development of tax population is represented by the largest number of indicators that can be combined into four subgroups:

- subgroup of economic indicators characterizing the level of economic development of the country for this purpose; two indicators: GDP per capita (including PPP), and the average annual GDP growth over 5 years;

- subgroup of financial performance measure of the state of public finances; includes two indicators: public debt in percentage of GDP and the budget deficit in percentage of GDP;

- subgroup of social indicators, presented by Gini index;

- subgroup of tax indicators directly characterizes the functioning of the tax system of the state and includes three indicators: (1) the level of tax burden shows the tax rate, measured as the ratio of total tax revenues (including social security fees) to GDP, (2) the number of tax payments (total tax payments), and (3) the time for fulfilling of (complying with) tax obligations (total tax time).

The last two indicators are used in the Paying Taxes rating and reflect ease of paying taxes by the typical enterprise in a country-specific tax system.

Since these indicators are heterogeneous, and some of them are correlated with others, we use factor analysis to reduce the initial set of indicators to a new set containing a smaller number of factors without significant loss of the original information. The factors are linear combinations of initial indicators by which the countries under study are most similar to, or different from, each other. The factors are uncorrelated with each other and allow us to get rid of "statistical noise".

Full information contained in the original set of parameters is reproduced by the same number of factors. But the first factor $(A)$ accounts for $41,4 \%$ variance in the initial set of indicators. The first and second main components combined $(A+B)$ account for more than half of the variation - 54,6\%, and the first six major components $(A+B+$ $+C+D+E+F$ ) for $80,8 \%$. Each successive component explains less than $5 \%$ variance. Therefore, further clustering of countries was made based on the first six factors.

Factor loadings can be interpreted as the correlations between the factors and the indicators (see Table 1). This allows us to give factors a meaningful interpretation.

The first factor $(A)$ is most closely related to the institutional factors (correlation coefficients ranged from 0,793 to 0,948 ) and 


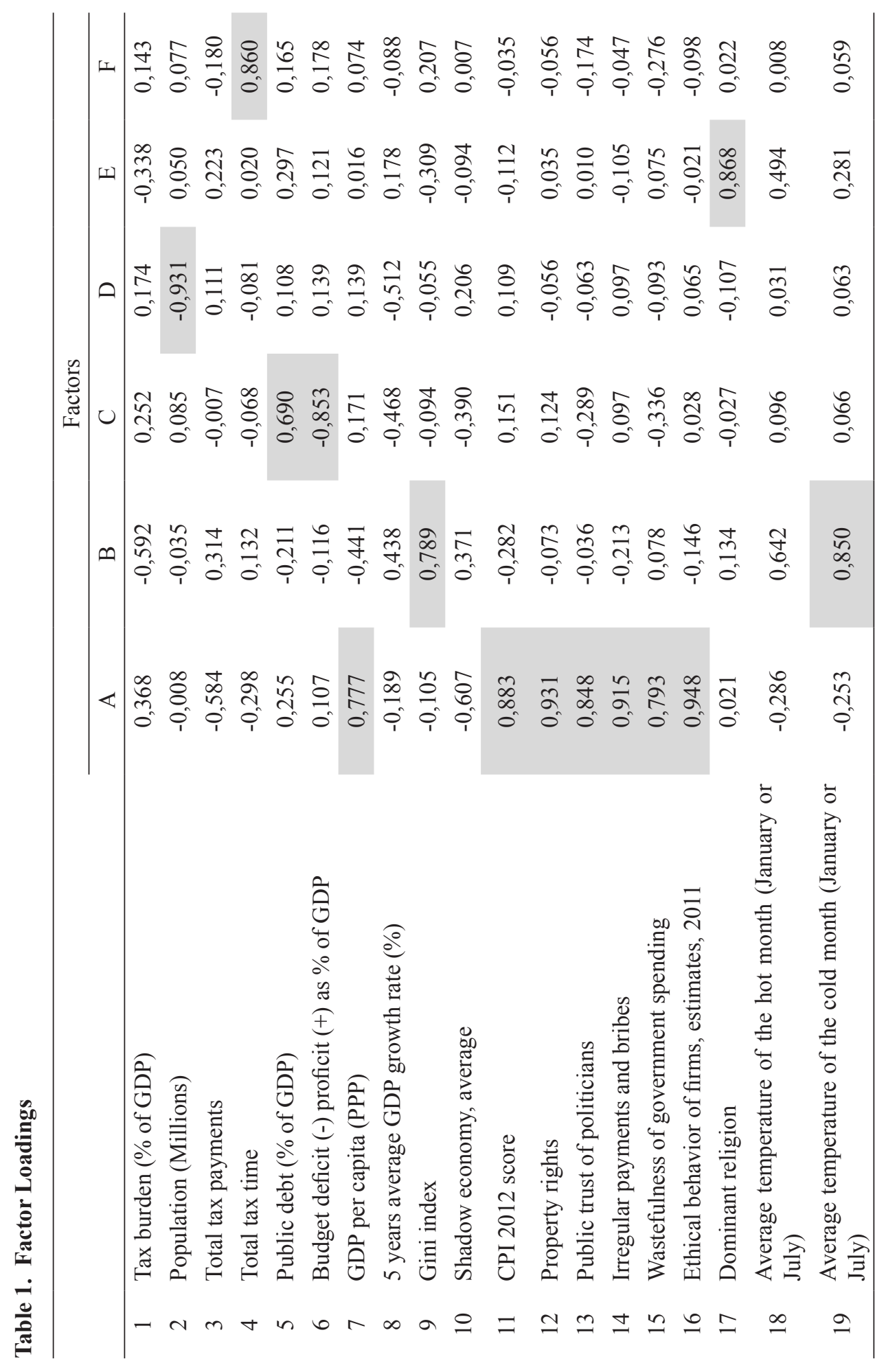


GDP per capita (correlation coefficient is 0,777 ). The correlation coefficients of other indicators with the first factor are shown in Table 1. This gives reason to interpret it as a projection of the original number of states in which the quality of their institutions is considered in a dialectical relationship with the welfare of the population.

The second factor $(B)$ explains the 13,2 $\%$ variance in the initial set of indicators. It is most closely related to the average temperature of the cold month, and the Gini coefficient (the correlation coefficients are 0,849 and 0,789 , accordingly). Both of these factors characterize the needs of governments in taxes: the first - due to the fact that low winter temperatures account for the high cost of ensuring the proper functioning of the transport infrastructure, maintenance and heating of public institutions, etc., and the second - due to the need to mitigate the problems of social inequality.

The third factor $(C)$, which accounts for $9,3 \%$ of the total variance, reflects the state of the public finances (correlation coefficient with a budget deficit of $-0,853$ and the level of public debt - 0,689). In this case, large values of the main components of $\mathrm{C}$ indicate a worse state of public finances.

The fourth, fifth and sixth factors account for $6,6 \%, 5,5 \%$ and $4,8 \%$ variance, respectively, and reflect the impact on inter-state differences in indicators such as population (factor $D$ ), the predominant religion (factor $E)$ and the standard enterprise cost of tax compliance (factor $F$ ).

The results of cluster analysis on the basis of thesesix factors are shown in Fig. 2.

Cluster 1 contains only two states - the fast-growing China and India. Separately presented in the figure is the rapidly developing Brazil - the largest in area and population among the countries of South America. Each of these large countries is unique in the evolutionary-biological (East Asians, South Asians, Europeans and Mulattoes) and civilizational-cultural (Confucianism, Buddhism, Catholicism) aspects, but together they make up the "core" of the new workshop of the world, intensive development of which is strongly influenced by the government using its resources, including tax, for active industrial policies [35].

Three relatively numerous clusters can also be identified in Figure 2. They are Clusters 3, 4 and 5.

Cluster 3 includes, mainly, the countries of Central and Southern Africa. These are developing third world countries, many of which share a common history of once being colonies of European countries, but then, after the breakup of the colonial system (decolonization), they faced the problems of formation of effective nation-states, as well as effective tax systems.

Cluster 4 combines highly developed North American and Western European countries. Patterns of socio-economic development, the relationship of citizens to the state and tax systems in these countries, are significantly similar because of their formation on the basis of Western values and legal norms, which can be generally characterized as liberal democracies. The countries in this cluster dominated throughout the twentieth century, but now, for various reasons, they are gradually losing their previous political and economic power [36].

Cluster 5 also includes a number of European countries, but these are the countries of the former Soviet Union, Eastern and Central Europe, as well as developed countries in Latin America (Argentina, Venezuela). Histories of many of these countries are associated with attempts to try to build a society and an economy, and thus a tax system, based on the ideals of socialism as an alternative to the Western European and North American capitalism. Now, many of them have abandoned the old ideologies and principles of farming in favor of those that are more inherent in a mixed economy, connected with the use of such options as a market mechanism and state development planning.

Cluster 6 is, on the one hand, the most numerous - it includes 42 of 117 countries 


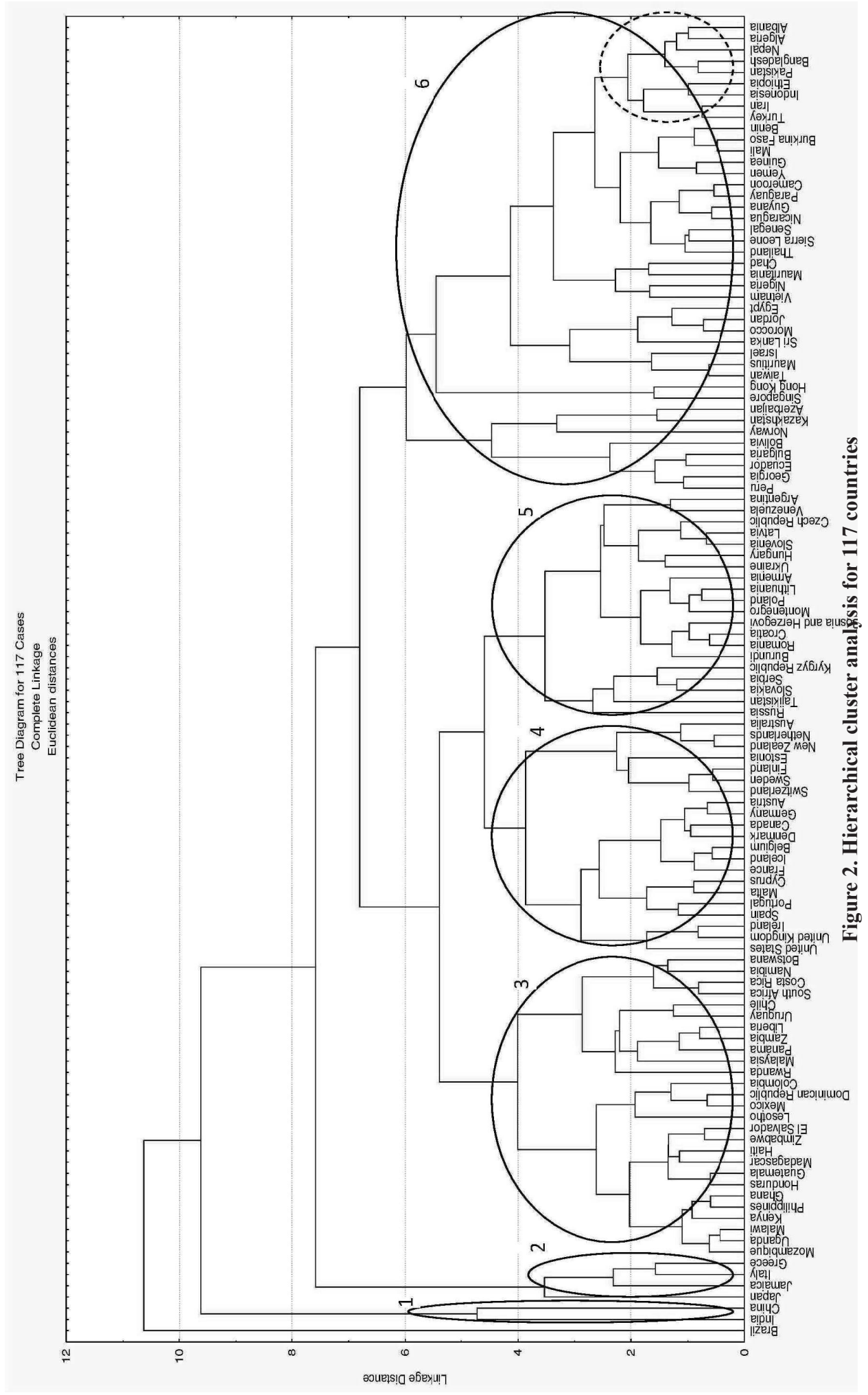


in the sample. On the other hand, its structure is very heterogeneous and includes mostly relatively small countries in Africa, Asia, South America, and Europe.

At the same time, as part of Cluster 6, the subcluster of Muslim countries in the Middle East and North Africa may be clearly defined. It is depicted as a broken line in Figure 2. The countries of the subcluster are characterized by rapid population growth. However, the growing relative influence of the Muslim countries in the world cannot be put down solelyt to the growing number of their citizens. Positive and, most importantly, stable economic performance is demonstrated by the countries which are members of the IDB (Islamic Development Bank). For example, Indonesia's economy has grown in recent decades, becoming more significant and more stable and diversified than many outside observers consider. And if today it is the 16th largest economy of the world, by 2030 it could enter the top ten and take seventh place in the world, ahead of major European countries such as Germany, the UK, or France [37]. These facts clearly contradict the long-held beliefs that Islam, in contrast to, for example, Christianity, is negatively correlated with production relations that contribute to the economic development [38, p. 280].

Finally, a quite interesting cluster is Cluster 2, including Japan, Greece, Italy and Jamaica. As for Greece, Italy and Jamaica, one would expect to see them in a cluster of European countries and Japan, next to other East Asian countries. In our view, the combination of these countries into a separate cluster has to do not so much with the long-term evolution of their tax systems, but with a specific situation after 20072008, when the aftermath of the financial crisis was a serious challenge not only to the national economies of these countries, but also to their financial systems.

Thus, our analysis has showen that in the world there are, indeed, groups of countries relatively homogeneous in selected indicators that can be interpreted as some supranational model of tax systems (tax populations of the developed Western European and North American countries, developing former socialist countries of Central and Eastern Europe and Latin American countries, Muslim countries, etc.).

However, interpreting the results of a cluster analysis, it is important to understand its limitations in addressing the problem of identification of tax populations. One of the main technical limitation is the difficulty of forming the initial array of indicators, including the lack of comparable international statistics on dynamics for a sufficiently long period of time. It should also be borne in mind that the statistics are organized by countries of the world, the composition and the boundaries of which are, to some extent, random variables [39]. In addition, the quality characteristics cannot always adequately reflect the quantitative indicators. It ismuch more relevant to take into account the influence of ethical norms of the dominant religion in the system of tax relations, and the like.

Therefore, to identify appropriate tax populations it is necessary to use the methods of logical analysis in addition to the results of a cluster analysis, allowing to form "perfect images" of such populations.

Logical analysis (creating patterns of tax populations). Building on the methodological approach which leans on the results of the cluster analysis, it is possible to single out the following main tax populations: the European, Chinese-East Asian, Maghrebi-Middle Eastern, and Indian-South Asian. Table 2 shows sub-populations of the European tax population and some countries representative of each tax population.

The European tax population, as the name implies, is represented by the Europeans (IQ - 90-107) [28, p. 16]) who are recognized as one of the major human races by all the classic anthropologists. The Europeans have spread far beyond the original area and now constitute a significant part of the population not only in Europe, but also on other continents (the North and 
South America, North Asia, and Australia), developed, among other ways, by displacing and eliminating the natives (in North America and Australia). Therefore, the European tax population consists of several sub-populations (Western European, North American, Australian, Latin American, and Eurasian). But the main one - generic is still the Western European population. The representatives countries are the UK, Germany, France, Italy, Spain. The predominant religion is Christianity (in its varieties developed under the influence of the Reformation), whose relation to the state and tax is characterized by Jesus Christ's response to the Pharisees, “... give to Caesar what is Caesar's and to God what is God's" (Gospel by Matthew, Matt. 22:15-22), and the meaning of which can be interpreted as that the service to God is separated from the service to the state and the problems of tax laws formation and compliance or noncompliance.

According to Max Weber, “... in the main, it has been the work of jurists to give birth to the modern Occidental 'state' as well as to the Occidental 'churches' " [33, p. 299], so that "... submission does not rest upon the belief and devotion to charismatically gifted persons, like prophets and heroes, or upon sacred tradition, or upon piety toward a personal lord and master who is defined by an ordered tradition, or upon piety toward the possible incumbents of office fiefs and office prebends who are legitimized in their own right through privilege and conferment. Rather, submission under legal authority is based upon an impersonal bond to the generally defined and functional 'duty of office" [33, p. 299].

The European demand for financing public infrastructure, determined, among other factors, by Europe's location in the northern latitudes and by the relatively low average annual temperature, is

\footnotetext{
6 Hereinafter the figures are calculated according to the World Bank, PricewaterhouseCoopers and Transparency International.
}

relatively high: tax revenues of the central government in the EU are traditionally high and now account for $19 \%$ of GDP (2012), or, calculated per capita, \$ 6,4 thousand (constant international PPP \$), including, for example, $\$ 8,4$ thousand/pers. in the UK, 5,8 in France, and 3,0 in Spain ${ }^{6}$. Tax legislation in the European countries, although complex, is well-developed, so that the transaction costs are relatively low: the United Kingdom ranks $14^{\text {th }}$ in the Overall Paying Taxes ranking (2014), and $14^{\text {th }}$ in the Corruption Perceptions Index (2014); France $-52^{\text {nd }}$ and $26^{\text {th }}$, respectively, Spain $-67^{\text {th }}$ and $37^{\text {th }}$, Germany $-89^{\text {th }}$ and $12^{\text {nd }}$, Italy $-138^{\text {th }}$ and $69^{\text {th }}$. Transaction costs are slightly lower in Northern Europe and they rise as we move down to the countries of Southern Europe. Given the differences in the levels of corruption and tax, one could speak about the different models of taxation within a given population (subpopulation). It is obviously, for example, that the AngloSaxon model of island taxation in Great Britain is very different from the continental model of Mediterranean Italy. But both of these models are still united by the European community. In this regard, it is important to note that it is not very productive to compare the tax systems of different countries, unless they belong to the same tax population with the same evolutionary-biological, civilizational-cultural, and socio-economic context.

Tax subpopulations of Latin America (representative countries: Argentina, Bolivia, Brazil, Venezuela) and Eurasia (representative countries: Belarus, Russia, Ukraine) are also formed by Europeans who profess Christianity, but in contrast to the Western European, North American and Australian sub-populations (which can be attributed to the Anglo-Saxon group), they have such distinctive features as traditionally more clannish and authoritarian government, as well as coexistence (not displacement) and a mixture of individual ethnic groups and cultures (e.g., in Brazil and Russia). Besides, the Latin American population has historically been 
predominantly Catholic, but the Eurasian one - Orthodox. The tax level, both in the Latin American and Eurasian populations, are somewhat lower than in Western Europe, in relative terms $(\approx 15-17 \%$ of GDP $)$, but significantly less $(\approx 2-6$ times $)$ in absolute terms: the central government taxes per capita with PPP in Bolivia comprise \$ 1,0 thousand/pers., in Brazil - 2,2, in Venezuela 2,7 , and further, in Ukraine - 1,5, in Belarus - 2,6, and in Russia — \$3,5 thousand/ pers. However, here the situation is much worse with the transaction tax costs - both in terms of the tax law convenience and in relation to corruption. For example, according to the Overall Paying Taxes ranking (2014), Argentina is the world's $153^{\text {rd }}$ and $107^{\text {th }}$ according to the Corruption Perception Index (2014); Brazil is $159^{\text {th }}$ and $69^{\text {th }}$, respectively, and Ukraine is $164^{\text {th }}$ and $142^{\text {nd }}$, Russia is $56^{\text {nd }}$ and $136^{\text {th }}$.

The Chinese-East Asian tax population is represented by the race of East Asians, often also referred to as Mongoloids (these include the indigenous people of China, Japan, Korea, Mongolia and Tibet [28]). IQ of the East Asians (100-120) is higher than that of the Europeans, which, apparently, can

\footnotetext{
Confucianism can be considered as a philosophy (world-view), and as a religion; however, in this case the difference does not matter, the important thing being that Confucianism is the core of the universally recognized norms and values: "East Asians may profess themselves to be Shintōists, Daoists, Buddhists, Muslims, or Christians, but, by announcing their religious affiliations, seldom do they cease to be Confucians" (Encyclopaedia Britannica 2012) [46].
}

Table 2. Main Tax Populations

\begin{tabular}{|c|c|c|c|c|}
\hline European & $\begin{array}{c}\text { Chinese-East } \\
\text { Asian }\end{array}$ & \multicolumn{2}{|c|}{$\begin{array}{c}\text { Maghrebi-Middle } \\
\text { Eastern }\end{array}$} & $\begin{array}{l}\text { Indian-South } \\
\text { Asian }\end{array}$ \\
\hline Sub-population & $\begin{array}{l}\text { Representative } \\
\text { countries }\end{array}$ & $\begin{array}{l}\text { Representative } \\
\text { countries }\end{array}$ & $\begin{array}{l}\text { Representative } \\
\text { countries }\end{array}$ & $\begin{array}{l}\text { R e p r e - } \\
\text { sentative } \\
\text { countries }\end{array}$ \\
\hline Western European & $\begin{array}{l}\text { France } \\
\text { Germany } \\
\text { Italy } \\
\text { Spain } \\
\text { UK }\end{array}$ & $\begin{array}{l}\text { China } \\
\text { Japan } \\
\text { Republic of Ko- } \\
\text { rea }\end{array}$ & $\begin{array}{l}\text { Egypt } \\
\text { Iran } \\
\text { Iraq } \\
\text { Libya } \\
\text { Saudi Arabia } \\
\text { Tunisia }\end{array}$ & $\begin{array}{l}\text { India } \\
\text { Nepal }\end{array}$ \\
\hline North American & $\begin{array}{l}\text { Canada } \\
\text { USA }\end{array}$ & & & \\
\hline Australian & $\begin{array}{l}\text { Australia } \\
\text { New Zealand }\end{array}$ & & & \\
\hline Latin American & $\begin{array}{l}\text { Argentina } \\
\text { Brazil } \\
\text { Bolivia } \\
\text { Venezuela }\end{array}$ & & & \\
\hline Eurasian & $\begin{array}{l}\text { Belarus } \\
\text { Russia } \\
\text { Ukraine }\end{array}$ & & & \\
\hline
\end{tabular}


be explained, in particular, by genetic factors [28, p. 96-97]. Representative countries are China, Japan, Republic of Korea (South Korea). The dominant ideology (religion) is Confucianism $^{7}$, which requires, on the one hand, that the functions of the government be carried out by the educated and morally blameless people, and, on the other hand, that each individual's behaviour be guided by the principle of acting for the good of the people and the state, not pursuing one's selfish interests. As emphasized by Fukuyama (1995) [40], in Confucianism, harmony and cooperation are preferred over disagreement and competition, and the maintenance of order and respect for hierarchy are central values. With regard to business ethics and tax rules, in contrast to the well-known European principles of Adam Smith, which are a little more than 200 years old, the Confucian tax rules are more than 2000 years old. They require restrictions to the rulers' taxation powers and moderate taxes for citizens (Adams 2001) [41, pp. 50-51]. This requirement is combined with the relatively warm climate of South-East Asia. Indeed, taxes here are traditionally lower than in Western Europe: in China they account for $11 \%$ of GDP or $\$ 1,1$ thousand/pers., in Japan - 10 $\%$ of GDP, or \$ 3,5 thousand/pers., in South Korea $-14 \%$ of GDP or $\$ 4,6$ thousand/ pers (2012). Judged by the time spent on tax obligations, the tax laws are more complicated in Japan and China, and less complicated in South Korea. Corruption in East Asian tax populations with the predominant Confucian outlook is relatively low: Japan perception index ranks $15^{\text {th }}$ in the world, South Korea $-43^{\text {rd }}$, and China $-100^{\text {th }}(2014)$.

The Middle East, Maghreb tax population includes inhabitants related to the race of South Asians and North Africans, whose IQ is, on average, slightly lower than that of the East Asians and Europeans [28, pp. 5455]. Representative countries are Iran, Iraq, Saudi Arabia, Syria, Egypt, Libya, Tunisia. Thus, this tax population includes those countries in the Middle East, which practice Islam. This is important, because Islam is not just a religion, but a factor of identity, spiritual and cultural traditions of the people, so that "[b]elonging to the Muslim community ... creates a special kind of solidarity that is based not only on a single religion, but also on the world-view resulting from the principles of Islam, on relations both to individuals and to the society as a whole, to ideas, and the nature of things" [42, p. 11].

A distinctive feature of Islamic doctrine is the unity of religion and state, spiritual and temporal power. In the domain of public finance and taxes, it is common use of public goods (mineral deposits, channels, dams, etc.) and the mandatory payment of special Muslim taxes, which include the zakat (a compulsory tax for the benefit of the poor), kharaj (a land tax), jizya (a poll tax), etc. [43]. Such taxes, in addition to raising funds for public needs, are designed "... to facilitate the movement of the society towards achievement of Islamic goals, and establishment of a just society" [43, p. 27]. The tax rate differs significantly in some countries of the population (depending on the presence of oil and gas fields ${ }^{13}$ ), but in general is relatively low. For example, in Egypt it accounts for $14 \%$ of GDP or $\$ 0,8$ thousand/pers., in Iran $-8 \%$ or $\$ 1,4$ thousand/pers., in Tunisia $-21 \%$ or $\$ 2,2$ thousand/pers (2012). Transaction costs related to the payment of taxes also depend on the characteristics of individual countries, but in general are much higher than in the West-European population. For example, assessed by the time spent on tax obligations, oil-producing Iran and Iraq are in the second hundred of countries (although oil producing Saudi Arabia occupies a higher position). Corruption in this region of the world is also considered to be relatively high.

The area of the Indian-South Asian tax population, also inhabited by South Asians and North Africans, as the name suggests, is the Indian subcontinent. Representative countries are populous India and Nepal, which are home to more than 1.2 bn people. The main common feature of this population is Hinduism which defines the characteris- 
tics of the dominant culture. Unlike in the West here, first, there is no strict division between the religious and socio-economic realities, while practical social norms are consistent with religious rules, so that the existing legal codes can be considered, among others, as an integral part of Hinduism $[40 ; 44]$. And, secondly, there is no central religious authority, establishing the rules of orthodoxy. This religion is characterized by the global perception of the world space (dharama) and futuristic vision (karma). In relation to the economy and wealth, Hinduism, like all great religions, warns people about the dangers of wealth accumulation, but it does not deny the rights of property, and, moreover, gives priority to the person over the state $[44$, p. 9]. In the area of taxes, according to the ethics of Hinduism, they must be defined and understood by taxpayers (the amount of tax, income taxed, and the time of payment), because otherwise the tax collectors could collect more than stipulated and assign a portion of the collected for their own benefit [45, pp. 140-141]. In practice, current taxes in the Indian population are not high, both in relative terms (as of 2010, the share of taxes in GDP in India was $11 \%$, and in Nepal $-15 \%$ ), and, especially in view of the relatively low per capita income, in absolute terms (in India $-\$ 0,5$ thousand/pers., and in Nepal - \$0,3 thousand/pers) (2012). Tax transaction costs in this population are also moderate.

\section{Conclusions}

To make a brief conclusion, it should be noted that the tax populations described above are presented as typical; therefore, they do not cover the whole planet or all the countries in the world. In many areas (let us call them "grey"), there are such mixtures of races, religions, cultures, institutions, or such specific historically determined conditions, that it does not seem possible to clearly define their population-tax affiliation. But over time, in the processes of global economic transformations, the situation with tax populations mapping may change significantly, and it will be possible to identify clearly some of the currently "grey" areas. A major factor in these changes is the increase (decrease) of races and migration of ethnic groups. The latter, as evidenced by the long-term European experience of relations with Muslim immigrants, do not always integrate into the host society, to say nothing of assimilation. Therefore, if some stable social groups, established as a result of the centuries-old process of gene-culture co-evolution, widen (narrow) its habitat, including the crossing of state borders, while maintaining its identity (such as, for instance, separate Islamic communities in Europe [47]), this leads eventually to a change in the tax populations mapping. Furthermore, populations themselves may gradually acquire new qualities determined by a change in their geographical location and increasing frequency of social mutation due to change or recombination of social replicators [10, p. 351]. But, as already noted, in various populations the same reasons - for example, introduction of new taxes or change of existing rates - lead to different consequences that go beyond the traditional neoclassical analysis of the excess tax burden and loss (or gain) of welfare.

Success criteria of tax population development are the relative (compared to other populations) increase in its numbers, the expansion of the range, and the increase of wealth ${ }^{8}$. Prevailing tax rules may be inefficient from the standpoint of conventional economic assessment of costs and benefits, or, for example, by the ease of paying taxes. But if those rules are adapted to the needs of a particular social group so as to allow it to expand its influence in the world, then they are performing well. This does not mean that the neoclassical recommendations on tax policy are unimportant in principle,

\footnotetext{
8 For example, you should consider the fact that the world's Muslim population is expected to increase by about $35 \%$ in the next 20 years, rising from 1,6 billion in 2010 to 2,2 billion by 2030 (Pew Research Centre's Forum on Religion \& Public Life 2011) [49].
} 
but they must be used, primarily, as a means of streamlining the tax system within the population with regard to its specific context, subject to evolutionary dynamics of the population growth, not as universal recipes for all occasions.

As has already been noted, a tax population is characterized not so much by formal fiscal rules (as a matter of fact, they can be similar in many countries) but by informal rules that determine people's sustainable attitudes to state and government institutions, and representatives of state and government — to the citizens. As noted by Schumpeter, “... nothing shows so clearly the character of a society and of a civilization as does the fiscal policy that its political sector adopts" [48, p. 736]. In this sense, a tax population is the financial "core" of civilization, as the recognition of power by people and their consent to obey it in such a population is not just declared, but confirmed by concrete actions for the disposal of part of the income or property in favour of the government.

Therefore, for the concept of tax populations, it is not the taxes themselves that are important, but the development, competition, and co-evolution of the various ways of organizing the social order and public services - processes that can change the political and economic map of the world and the dominant view of effective taxation and efficient state. So, perhaps, in the near future the U.S. and Western Europe will be replaced by China (Chinese-East Asian tax population) and India (Indian-South Asian tax population) as the world examples, demonstrating in practice their efficiency as states and showing how to build a relationship of citizens and businesses with authorities and how to use taxes to deal with the challenges of sustainable economic development and social welfare of citizens. This is especially important for Russia, which has chosen a strategic alliance with China and a new - Eastern - vector of development, relying not on the Euro-Atlantic, but the Eurasian political values and seeing Eurasia as a special geographic, historical, social, and cultural integrity.

\section{References}

1. Lindahl E. Just taxation - a positive solution (1919) / Erik Lindahl // Classics in the theory of public finance; ed. R. Musgrave and A. Peacock. - New York: Macmillian, 1958. - Pp. 168-176.

2. Hicks J. The Foundations of Welfare Economics / John R. Hicks // The Economic Journal. - 1939. - Vol. 49, № 196. - Pp. 696-712.

3. Musgrave R. The Theory of Public Finance: A Study in Public Economy Richard A. Musgrave. - New York: McGraw-Hill, 1959. — 628 pp.

4. Musgrave R. Public Finance in Theory and Practice / Richard A. Musgrave, Peggy B. Musgrave; Fourth ed. — New York: McGraw-Hill, 1984. — 824 pp.

5. Atkinson, A. Lectures on public economics / Anthony B. Atkinson, Joseph E. Stiglitz. - New York: McGraw-Hill, 1980. - 620 pp.

6. Rosen H. Public Finance/ Harvey S. Rosen, Ted Gayer. - Singapore: McGraw-Hill, 2008. - 640 pp.

7. Simon H. Bounded Rationality and Organizational Learning / Herbert A. Simon // Organization Science. - 1991. — Vol. 2, № 1. — Pp. 125-134.

8. Diamond J. Guns, Germs, and Steel: the Fates of Human Societies / Jared Diamond. - New York: W. W. Norton \& Company, 1994. - 480 pp.

9. Witt $U$. What is specific about evolutionary economics? / Ulrich Witt // Journal of Evolutionary Economics. - 2008. - Vol. 18, № 5. - Pp. 547-575.

10. Stoelhorst J.-W. The Explanatory Logic and Ontological Commitments of Generalized Darwinism / Jan-Willem Stoelhorst // Journal of Economic Methodology. - 2008. - Vol. 15, № 4. - Pp. 343-363.

11. Aldrich H. In defence of generalized Darwinism // Howard E. Aldrich, Geoffrey M. Hodgson, David L. Hull, et al. // Journal of Institutional 
Economics. - 2008. - Vol. 8, № 5. Pp. 577-596.

12. Nelson R. Universal Darwinism and evolutionary social science / Richard R. Nelson // Biology and Philosophy. - 2007. - Vol. 22, № 1. - Pp. 73-94.

13. Wilson D. Rethinking the Theoretical Foundation of Sociobiology / David Sloan Wilson, Edward O. Wilson // The Quarterly Review of Biology. 2007. - Vol. 82, № 4. — Pp. 327-348.

14. Bloomquist K. Tax compliance as an evolutionary coordination game: an agent-based approach / Kim Bloomquist // Public Finance Review. — 2011. - Vol. 39, № 1. — Pp. 25-49.

15. Christians A. Historic, Comparative and Evolutionary Analysis of Tax Systems / Allison Christians // University of Wisconsin Legal Studies Research Paper. - 2010. - № 1131. $-26 \mathrm{pp}$.

16. Garbarino C. An Evolutionary Approach to Comparative Taxation: Theory, Methods and Agenda for Research / Garbarino, Carlo. // Bocconi Legal Studies Research Paper. Milan: Bocconi University. - 2007. $-23 \mathrm{pp}$.

17. John P. Ideas and interests; agendas and implementation: an evolutionary explanation of policy change in British local government finance / John, Peter // British Journal of Politics and International Relations. - 1999. Vol. 1, № 1. - Pp. 39-62.

18. Steinmo $\mathrm{S}$. The evolution of policy ideas: tax policy in the 20th century / Steinmo, Sven // British Journal of Politics and International Relations. - 2003. - Vol. 5, № 2. - Pp. 206-236.

19. Simon H. Altruism and economics / Herbert Simon // The American Economic Review. - 1993. - Vol. 83, № 2. - Pp. 156-161.

20. Langer P. Spatial Invasion of Cooperation / Philipp Langer, Martin Nowak, Cristoph Hauert // Journal of Theoretical Biology. - 2008. - Vol. 250, № 4. - Pp. 634-641.

21. Hodgson G. The Mystery of the Routine. The Darwinian Destiny of an Evolutionary Theory of Economic Change / Geoffrey M. Hodgson // Revue Economique. - 2003. - Vol. 54, № 2. - Pp. 355-384.

22. Hodgson G. The concept of a routine / Geoffrey M. Hodgson // Handbook of Organizational Routines; ed. by Markus C. Becker. - Cheltenham, UK, Northampton, MA, USA: Edward Elgar Publishing Limited, 2008. - Pp. 15-28.

23. Becker M. The past, present and future of organizational routines / Markus C. Becker // Handbook of Organizational Routines; ed. by Markus C. Becker. - Cheltenham, UK, Northampton, MA, USA: Edward Elgar Publishing Limited, 2008. - Pp. 3-14.

24. Becker M. Organizational Routines: a Review of the Literature / Markus C. Becker // Industrial and Corporate Change. - 2004. - Vol. 13, № 4. Pp. 643-677.

25. Robson A. The Biological Basis of Economic Behavior / Arthur Robson // Journal of Economic Literature. - 2001. - Vol. 39, № 11. - Pp. 11-33.

26. Palmer J. Evolutionary Psychology. The Ultimate Origins of Human Behavior / Jack A. Palmer, Linda K. Palmer. - Boston, MA: Allyn and Bacon, 2002. - 304 pp.

27. Schaffer E. What Makes A Nation Intelligent? [online] / Eric Schaffer, 2011. - Available at: http://www. psychologicalscience.org/index.php/ video/aps-award-address-2.html. 23.05.2015.

28. Lynn R. Race Differences in Intelligence: an Evolutionary Analysis / Richard Lynn. - Washington: Summit Publishers Augusta, GA, A National Policy Institute Book, 2006. — 205 pp.

29. Tayyari F. The genetic basis of intelligence [online] / Farnoosh Tayyari // The Science Creative Quarterly, 2004. — Available at: http:// www.scq.ubc.ca/the-genetic-basis-ofintelligence. - 23.05.2015.

30. Richerson P. Not by Genes Alone: How Culture Transformed Human Evolution / Peter J. Richerson, Robert Boyd. - 
Chicago, London: University of Chicago Press, 2005. - 344 pp.

31. Richerson P. Gene-culture coevolution in the age of genomics / Peter J. Richerson, Robert Boyd, Joseph Henrich // Proceedings of the National Academy of Science of the United States of America. - 2010. - Vol. 107, № 2. - Pp. 8985-8992.

32. Huntington S. The Clash of Civilizations and the Remaking of World Order / Samuel P. Huntington. - New York: Simon \& Schuster, 1996. - $367 \mathrm{pp}$.

33. Weber M. The Social Psychology of The World Religions / Max Weber // From Max Weber: Essays in Sociology ed. by Hans H. Gerth and C. Wright Mills. - New York: Oxford University Press, 1946. - Pp. 267-301.

34. Buehn A. Shadow economies around the world: novel insights, accepted knowledge, and new estimates / Andreas Buehn, Friedrich Schneider // International Tax and Public Finance. - 2012. - Vol. 19, № 1. - Pp. 139-171.

35. OECD. Perspectives on Global Development 2013: Industrial Policies in a Changing World. Shifting up a Gear. — OECD Publishing, 2013. - 18 pp.

36. National Intelligence Council. Global Trends 2030: Alternative Worlds. -National Intelligence Council Publishing, 2012. - $140 \mathrm{pp}$.

37. McKinsey Global Institute. The archipelago economy: Unleashing Indonesia's potential. - McKinsey Global Institute Publishing, 2012. $101 \mathrm{pp}$.

38. Guiso L. People's opium? Religion and economic attitudes / Luigi Guiso, Paola Sapienza, Luigi Zingales // Journal of monetary economics. - 2003. — Vol. 50, № 1. - Pp. 225-282.

39. Wallerstein I. Does India Exist / Immanuel Wallerstein // The Essential Wallerstein. - New York: The New Press, 2000. - Pp. 310-314.
40. Fukuyama F. Confucianism and Democracy / Francis Fukuyama // Journal of Democracy. - 1995. Vol. 6, № 2. - Pp. 20-33.

41. Adams Ch. For Good and Evil: the Impact of Taxes on the Course of Civilization / Charles Adams. Lanham, New York, Oxford: Madison Books, 2001. - 539 pp.

42. Mirskij G. Islam: the History and the Present / Georgy N. Mirskij // Novaya i Noveishaia Istoria Journal. — 2010. — № 1. - Pp. 1-39.

43. Jalili A. A Descriptive Overview of Islamic Taxation / Ali Reza Jalili // Journal of American Academy of Business. - 2006. - Vol. 8, № 2. Pp. 16-28.

44. Gomez-Zimmerman M. The Capitalist Structures of Hinduism / Mario Gomez-Zimmerman // Religion \& Liberty. - 1996. - Vol. 6, № 3. Pp. 8-10.

45. Bose S. Hindu Ethical Considerations in Relation to Tax Evasion / Sanjoy Bose // The Ethics of Tax Evasion. Perspectives in Theory and Practice; ed. by Robert W. W. McGee. - New York: Springer, 2012. — Pp. 135-147.

46. Encyclopædia Britannica Inc. Confucianism [online]. Available at: http://www.britannica. com/EBchecked/topic/132104/ Confucianism. - 23.05.2015.

47. Kern S. French Suburbs Becoming 'Separate Islamic Societies' [online] / Soeren Kern, 2011. - Available at: http://www.gatestoneinstitute. org/2487/french-suburbs-islamicsocieties. - 23.05.2015.

48. Schumpeter J. History of Economic Analysis / Joseph A. Schumpeter. London: Allen \& Unwin (Publishers) Ltd., 1954. - 1283 pp.

49. Pew Research Center's Forum on Religion \& Public Life. The Future of the Global Muslim Population: Projections for 2010-2030. — Washington, D.C.: Pew Research Center, 2011. — 209 pp. 
В. П. Вишневский , д-р экон. наук, профессор, г. Киев, Украина

А. В. Гурнак, канд. экон. наук, доцент, г. Москва, Россия

\section{НАЛОГООБЛОЖЕНИЕ, ЭВОЛЮЦИОННАЯ ЭКОНОМИКА И НАЛОГОВЫЕ популяции}

Аннотация. В статье предложено использование эволюционного подхода к исследованию налогообложения, который в отличие от неоклассической экономики и институционализма сфокусирован на долгосрочной перспективе и популяционных детерминантах развития налоговых систем. Такой подход является элементом новой эволюционной налоговой парадигмы. Стержневая идея этой парадигмы - идея о налоговых популяциях, ареалы которых могут не совпадать с границами государств, поскольку последние исторически случайны и зачастую объединяют людей, принадлежащих к различным генетическим и социально-культурных общинам. Представлены эмпирические и логические результаты исследования основных налоговых популяций. Эмпирические результаты основаны на использовании метода кластеризации для выборки из 117 стран мира. Проведенный анализ показал, что в мире действительно существуют группы относительно однородных стран, которые могут быть истолкованы как наднациональные модели налоговых систем. Полученные кластеры и логический анализ социально-экономического развития различных стран мира позволили выявить и описать наиболее значимые особенности основных налоговых популяций, которыми являются европейская, китайско-восточноазиатская, ближневосточно-магрибская и индийско-южноазиатская налоговые популяции. Концепция налоговых популяций предлагает новую методологическую базу для налоговой политики и реформирования налоговых систем. Это не означает, что неоклассические рекомендации в отношении налоговой политики и налоговых реформ не важны в принципе, однако они должны быть использованы преимущественно как средство формирования налоговой системы в соответствии с траекторией развития той или иной налоговой популяции и учетом ее специфического контекста, а не как универсальные рецепты на все случаи жизни.

Ключевые слова. Налогообложение; методология; эволюционная экономика; институты; налоговая популяция; налоговая система; налоговая реформа.

\section{Сведения об авторах}

Вишневский Валентин Павлович - доктор экономических наук, профессор, академик НАН Украины, заместитель директора по научной работе Института экономики промышленности НАН Украины, г. Киев, Украина (01011, г. Киев, ул. П. Мирного, 26); e-mail: vvishn@mail.ru.

Гурнак Александр Владимирович - кандидат экономических наук, доцент кафедры налогов и налогообложения Финансового университета при правительстве Российской Федерации, г. Москва, Россия (125993, г. Москва, просп. Ленинградский, 49); e-mail: gurnak@rambler.ru. 